\title{
KEBIJAKAN PENGGUNAAN MODA TRANSPORTASI UMUM UNTUK KESEJAHTERAAN EKONOMI MASYARAKAT KOTA SEMARANG
}

\author{
Sukarmi, Deny Suwondo \\ Fakultas Hukum, Universitas Islam Sultan Agung \\ Jl. Raya Kaligawe KM 4, Semarang, 50114 \\ sukarmi@unissula.ac.id
}

\begin{abstract}
The high flow of urbanization in the city of Semarang with the awareness of the low society using public transportation has led to congestion which has resulted in a decline in economic prosperity. (RKPD, 2016: 16). Research conducted to follow up on previous policies from the results of discussion and analysis that considered negative because it was not thoroughly reviewed and controlled. Congestion occurs because the number of vehicles used is not balanced with the available road capacity, even modes of public transport services that have small capacity require inefficiency. The development of dense public transport, with the reduction of routes must be collected with a larger capacity mode. Analysis of sociological juridical research with analytical descriptive specifications. The occurrence of congestion is caused by internal and external factors. Internal efforts are carried out by changing the mindset of the people, doing "public education", and "mental revolution", with the example of stakeholders, so that the community's initial awareness of the habits of private vehicle users is updated to public vehicles.
\end{abstract}

Keywords: Congestion, public education, welfare

\begin{abstract}
Abstrak
Arus urbanisasi tinggi Kota Semarang dengan rendahnya kesadaran masyarakat menggunakan transportasi umum menimbulkan kemacetan yang berdampak terjadi kemerosotan kesejahteraan ekonomi. (RKPD, 2016:16). Penelitian dilakukan untuk menindak lanjuti kebijakan sebelumnya dari hasil identifikasi dan analisis cenderung berdampak negative karena tidak dikaji dan dikontrol secara komprehensif. Kemacetan terjadi karena jumlah kendaraan yang digunakan tidak seimbang dengan kapasitas jalan yang tersedia, bahkan moda pelayanan angkutan umum yang ada berkapasitas kecil menimbulkan inefisiensi. Pengembangan untuk daerah dengan rute angkutan umum yang padat, dengan reduksi trayek harus diikuti konversi moda berkapasitas lebih besar. Pendekatan penelitian yuridis sosiologis dengan spesifikasi deskriptif analitis. Terjadinya kemacetan disebabkan oleh faktor internal dan eksternal. Upaya internal dilakukan dengan mengubah mind set masyarakat, melakukan "edukasi publik", dan "revolusi mental", dengan peneladan stakeholder, sehingga terbangun kesadaran masyarakat semula kebiasaan pemakai kendaraan pribadi secara bertahap ke kendaraan massal (publik).
\end{abstract}

Kata kunci: Kemacetan; edukasi publik; kesejahteraan 


\section{A. Pendahuluan}

\section{Latar Belakang Masalah}

Transportasi salah satu pembinaan sarana perhubungan berfungsi memindahkan sesuatu dari satu tempat ke tempat lain. Salah satu jenis transportasi yang beroperasi di Indonesia adalah transportasi darat seperti kendaraan bermotor dan kereta api yang operasional masing-masing sarana transportasi disesuaikan dengan kebutuhan konsumen. Pengembangan transportasi cenderung berdampak negative karena tidak dikaji dan dikontrol dengan baik (tidak komprehensif) dan berdampak macet karena jumlah kendaraan bermotor yang digunakan tidak seimbang dengan kapasitas jalan yang tersedia. Jumlah pendudk Kota Semarang kategorinya sebagai kota metropolitan dipergunakan parameter kemajuan koota-kota lain Propinsi Jawa Tengah. ( Riptek Vol.10. No. 1, Tahun 2016). Penyeimbangan rasio jumlah angkutan umum dan kendaraan pribadi untuk efisiensi waktu perjalanan kurang dipertimbangkan. Kebijakan tepat perlu dilakukan dengan sinkronisasi mengubah mind set masyarakat, menyadarkan dan merubah kebiasaan penggunaan kendaraan pribadi secara bertahap ke transportasi publik sesuai program yang digalakkan Pemerintah Daerah Provinsi Jateng.

Upaya pencegahan telah dilakukan dengan pembangunan, perbaikan sarana prasarana perhubungan darat, seperti pembangunan jalan tol/by pass, fly over, penyediaan angkutan umum dan perluasan jalan, tetapi tidak dapat mengurangi kemacetan yang terjadi. Salah satu Konsep pembangunan berkelanjutan berawal dari pentingnya kesadaran berbagai pihak isu lingkungan global seperti pembangunan berkelanjutan (sustainable development) ${ }^{1}$. Pembangunan yang ditujukan untuk memenuhi kesejahteraan ( Journal Systems, Vol 8, No 16 (2010),kebutuhan generasi sekarang tanpa mengorbankan kepentingan dan kebutuhan generasi yang akan datang. Kendaraan umum massal (BRT) yang beroperasi di Kota Semarang telah ada dan telah berjalan baik, namun operasionalisasi, fasilitas dan pelayanannya masih belum optimal. Penambahan koridor, penyediaan jumlah terminal dan sub terminal, penyediaan halte meliputi cakupan wilayah pada titik-titik penting telah ditingkatkan. Penyeimbangan rasio jumlah angkutan umum dan kendaraan pribadi untuk efisiensi waktu perjalanan kurang dipertimbangkan. Disisi lain memberdayakan pengembangan kultur masyarakat, mengubah mind side masyarakat, membiasakan memanfaatkan trasportasi umum sebagaimana diharap oleh Kebijakan Walikota Nomor 19 Tahun 2009 tentang Pelaksanaan Hari Bebas Kendaraan Bermotor harus diefektifkan.

\section{Kerangka Teori}

(1) Hans Kelsen dalam Stufent Bau Theori sebagai pisau analisis peraturan yang diperuntukkan sebagai dasar kebijakan masyarakat guna mengurai kemacetan lalulintas telah sesuai dengan norma peraturan yang lebih tinggi. Bahkan dalam Principle of Legality Lon L. Fuhler, hukum sebagai sistem harus memenuhi delapan (8) azas atau principles of legality sebagai : a) Sistem hukum tidak boleh mengandung sekedar keputusan yang bersifat ad-hoc; b) Peraturan yang telah dibuat itu harus diumumkan; c) Peraturan tidak boleh berlaku surut; d) Peraturan disusun dalam rumusan yang bisa dimengerti; e) Suatu sistem tidak boleh mengandung peraturan bertentangan satu sama lain; f) Peraturan tidak boleh mengandung tuntutan yang melebihi apa yang dapat dilakukan; g) Peraturan tidak boleh sering diubah-ubah; $h$ ) Harus ada kecocokan antara peraturan yang diundangkan dengan pelaksanaannya sehari-hari. Sementara itu (2) Lawrence Friedman (Teori Sistem Hukum), memandang hukum sebagai satu kesatuan sistem diperlukan pendekatan sistem yang terdiri dari tiga komponen yakni struktur, substansi, dan kultur.(Lawrence Friedman, 1986). Teori ini menyangkut nilai-nilai, sikap-sikap, persepsi, custom, ways of doing, ways of thingking, opinion, mempengaruhi bekerjanya hukum. Kultur berfungsi sebagai 
jembatan menghubungkan antara peraturan hukum dengan tingkah laku hukum seluruh warga masyarakat. (3) Teori Pendekatan Birokrasi Yehezkel Dror ada perluasan sudut pandang hukum sebagai satu kesatuan sistem hukum yang terkait dengan mekanisme penegakan hukum yang melibatkan berbagai macam komponen saling berhubungan memiliki keterkaitan erat. Jika salah satu komponen tidak ada dapat menyebabkan inefficient maupun useless, karena tujuan hukum sulit terwujud. Komponen tersebut meliputi personel, information, budget, facilities substantive law, procedural law, decision rules dan decision habbits. (Yehezkel Dror,1971).

Penelitian sebelumnya telah dilakukan, tetapi dilakukan tidak secara komprehensif, tidak tuntas dan tidak ada kontrol dengan baik. Sehingga berdampak cenderung negative, terjadi ketidakseimbangan antara jumlah penduduk dengan kepemilikan kendaraan, serta tidak ada keseimbangan perbaikan sarana prasarana perhubungan darat. Disisi lain kendaraan dari luar kota Semarang yang melewati setiap harinya selalu bertambah.

Terjadi Gap Analysis antara fakta yang terjadi dengan kebutuhan yang diharapkan. Penelitian sebelumnya yang dilakukan masih sepotong-potong, sehingga perlu dilakukan penelitian lanjutan secara komprehensif, sehingga penelitian ini bersifat "unik" karena berjuang untuk mencapai efektifitas berlakunya UUNo. 22 tahun 2009 Tentang LLAJ dan kebijakan SK. Gubernur Jawa Tengah Nomor 550/54 Tahun 2015 dan Surat Edaran Sekretaris Daerah Provinsi Jawa Tengah Nomor 550/016847 Tentang Penerapan Hari Bebas Kendaraan Bermotor. Penelitian ini secara spesifik bertujuan mengubah mind set masyarakat, menyadarkan dengan membiasakan menggunakan kendaraan pribadi beralih ke kendaraan publik secara bertahap. Upaya implementasi kebijakan Gubernur dengan Program Hari Jumat Bebas Kendaraan bagi PNS Propinsi Jawa Tengah, secara langsung bersama-sama dengan masyarakat mengendarai sepeda "ontel" berangkat menuju kantor Gubernur. Kegiatan ini diikuti oleh masyarakat pegawai dilingkungan Kantor Pemerintah ini, walaupun sebagian pegawai masih tetap menggunakan kendaraan pribadi.

Suatu hal yang mengejutkan adalah semakin tinggi jumlah kendaraan pribadi, semakin menurun pengguna angkutan umum diberbagai perkotaan (urban areas) (Malkhamah,S, 2007). Oleh karena itu langkah bijak yang tepat adalah Pimpinan memberikan keteladanan, memberikan "edukasi publik" dengan melakukan "revolusi mental".

\section{B. Metode Penelitian}

Metode pendekatan yuridis sosiologis dengan spesifikasi penelitian deskriptif analisis dengan menekankan pada pengamatan dan observasi terhadap tingkah laku pemakai jalan/pengendara kendaraan. Populasi diambil dari masyarakat pengendara kendaraan di jalan raya umum, baik masyarakat Kota Semarang maupun masyarakat yang melewati jalan raya Kota Semarang.

Teknik pengumpulan data melalui pengamatan, wawancara mendalam pada informan, Pengumpulan data dilakukan dengan menggunakan teknik wawancara dan observasi. dilanjutkan penelitian data sekunder yang terdapat pada studi kepustakaan melalui langkah teoritik, metode analisis bersifat kualitatif yang dicatat dalam bentuk laporan.

\section{Hasil Penelitian dan Pembahasan}

Dampak kemacetan seperti Pemborosan BBM, Polusi udara, Pemborosan waktu, Membuat stress dan Mengeluarkan biaya lebih telah mempengaruhi perekonomian masyarakat. (http://repository.umy.ac.id/handle/123456 789/8909) Jika dibiarkan dalam jangka waktu panjang, maka berdampak jauh dari tujuan kesejahteraan ekonomi masyarakat. Kesejahteraan menurut ukuran UNDP indikatornya pendapatan per kapita, panjangnya masa hidup dan tingkat 
pendidikan yang dapat diraih. (Mark Mc Gillivray, 1991) Indikator bisa juga diukur berdasar

Prosperity Index,(http://www.prosperity.com/) Quality of Life Index, (http://www.numbeo) maupun Index Kesejahteraan Rakyat (IkraR)

(http://datakesra.menkokesra.go.id/datakesr a/kemiskinan_pemberdayaan/data-indekskesejahteraan-rakyat-ikrar) dan sebagainya. Kondisi demikian ini "Moda transportasi umum" menjadi semakin penting, demikian juga dalam dunia perdagangan, pengangkutan ini memegang peran mutlak, sebab tanpa pengangkutan perusahaan akan mengalami kesulitan untuk berjalan. (http://iinsetya14.blogspot.

co.id/2015/12/bab-i-pendahuluan-

i.html) Nilai suatu barang tidak hanya tergantung dari barang itu sendiri, tetapi tergantung pada tempat dimana barang itu berada, sehingga dengan pengangkutan nilai suatu barang akan meningkat.

Walaupun Kebijakan Transportasi Umum Kota Semarang sampai saat ini masih belum bisa berhasil tuntas, untuk mengimplementasikan kebijakan yang dicanangkan Gubernur Jateng No. 550/54 Tahun 2015 dan S E Sekda Prop. Jateng No. 550/016847 tentang Penerapan Hari Bebas Kendaraan Bermotor Bagi Instansi Pemprop Jateng Tahun 2015 sampai tahun 2020 tentang Larangan penggunakan sarana transportasi kendaraan bermotor pribadi dan kendaraan bermotor dinas bagi seluruh Pegawai Negeri Sipil dan Non Pegawai Negeri Sipil di Lingkungan Dinhubkominfo Provinsi Jateng, (Jurnal Media Center Kominfo Jawa Tengah) kecuali tugas di luar lingkungan kerja atas persetujuan atasan masingmasing. Kebijakan tersebut harus ditegakkan, karena terhubung erat dengan masalah kesejahteraan ekonomi masyarakat. (Carles Himawan, 2006) Kesejahteraan pada umumnya difahami dalam koridor ekonomi Barat dan unsur materialisme, hedonisme tanpa memperhatikan unsur agama. Namun yang terjadi dalam kehidupan adalah berbeda, seperti yang terjadi Norwegia sebagai Negara paling sejahtera memiliki angka bunuh diri yang cukup tinggi yaitu 28 orang setiap 100.000 jiwa. Dibandingkan dengan Mesir yang menduduki peringkat 112 dalam HDI , angka bunh dirinya hanya 0,1 dari 100.000 jiwa. (Satria Hibatal Azizy, 2015) Demikian juga masyarakat Indonesia dengan penduduk mayorias Islam, walaupun mungkin tingkat HDI rendah tetapi masyarakatnya lebih bahagia dan sejahtera untuuk menimati kehidupan di dunia karena menikmati "kesejahteraan" mereka sendiri tanpa terbawa arus materialism. Hal ini bisa dikatakan bahwa Islam memiliki pemahaman berbeda dengan pemahaman yang muncul di Barat. Islam memandang kesejahteraan dalam dua dimensi, yaitu dimensi duniawi dan ukhrawi dimana lebih dominan dalam penentuan kesejahteraan manusia, ada keseimbangan.

Sehingga mengubah mind set masyarakat, menyadarkan dengan merubah kebiasaan penggunaan kendaraan pribadi beralih ke kendaraan umum/publik secara bertahap menjadi sesuatu yang seharusnya. Tentunya jika telah sarana dan prasarana telah memadai dan jika yang lebih mengena dengan diilakukannya "teladan bijak dari stakeholder" atau "edukasi publik" atau dilakukannya "revolusi mental". Upaya implementasi kebijakan tersebut dapat juga dilakukan kegiatan secara langsung bersama-sama dengan masyarakat mengendarai sepeda "ontel" (Sepeda "ontel" yaitu sepeda tradisional) berangkat menuju kantor Gubernur. Kegiatan ini diikuti oleh masyarakat pegawai dilingkungan Kantor Pemerintah ini.

Angkutan umum menurut Lyon (2001) dibutuhkan untuk memberikan derajat fleksibilitas yang tinggi untuk menyaingi secara efektif mobil pribadi atau yang diistilahkan dengan mobilitas personal (perorangan). (Jurnal Transportasi Vol. 9 No. 1 Juni 2009: 36-47). Perkembangan Sistem Pelayanan Angkutan Umum di Indonesia sejak tahun 60-an lebih 
didasarkan pada sistem jaringan jalan raya dan terjadi tanpa pengendalian yang memadai. Pengembangan sistem transportasi perkotaan menurut Parikesit (2007) harus dilakukan secara konsisten dan didasarkan atas rencana yang peka terhadap karakteristik lokal. Hal ini bertolak belakang dengan hasil penelitian sebelumnya yang dilakukan secara tidak komprehensif.

Pemodelan transportasi perkotaan di negara berkembang perlu memanfaatkan perkembangan terbaru dalam bidang penginderaan jauh untuk mengakomodasi perubahan cepat penggunaan lahan. (Parikesit, D. 2007.) Kebijakan Pemerintah juga harus berubah sesuai keinginan local. Maka teori Principle of Legality Lon L. Fuhler, dimana terdapat delapan asas seperti delapan azas atau principles of legality, seperti "Peraturan tidak boleh sering diubah-ubah" tidak sesuai lagi sehingga bisa diterapkan dalam permasalahan ini. Jika Laurance Friedman yang dapat mempengaruhi bekerjanya hukum meliputi "kultur" berfungsi sebagai jembatan menghubungkan antara peraturan hukum dengan tingkah laku hukum seluruh warga masyarakat. Hal inilah lebih tepat untuk dimmplementasikan dalam kondisi sedang berubah.

Sejauh ini PNS dilingkungan Propinsi Jawa Tengah terbukti "masih melanggar kebijakan", sangsi yang diberlakukan masih berupa "pembinaan", jika di kemudian waktu masih tetap melakukan pelanggaran kebijakan tersebut baru akan dikenai sanksi tegas. Simorangkir dan Wirjono Sastropranoto bahwa hukum bersifat memaksa, menentukan tingkah laku manusia dalam masyarakat yang dibuat oleh badan-badan resmi yang berwajib, pelanggaran-pelanggaran terhadap peraturan tadi berakibat diambilnya tindakan yaitu dengan hukum tertentu. ( http://iinsetya14.

blogspot. co.id/2015/12/bab-ipendahuluan-i.html December 20, 2015). Ditinjau dari Principle of Legality Lon L.Fuhler, bahwa hukum sebagai sistem tidak boleh sering diubah-ubah dan harus ada kecocokan antara peraturan yang diundangkan dengan pelaksanaan seharihari. Simorangkir dan Wirjono Sastropranoto hukum menyampaikan, bahwa hukum berupa peraturan-peraturan bersifat memaksa, menentukan tingkah laku manusia dalam masyarakat dibuat badanbadan resmi, sehingga pelanggaran terhadap peraturan berakibat diambilnya tindakan dengan hukum tertentu. (Hukum Pengangkutan, Pengangkutan Darat > http://iinsetya 14 .

blogspot. co.id/2015/12/bab-ipendahuluan-i.html December 20, 2015).

Evaluasi cermat dengan memberikan edukasi publik berupa keteladanan optimal dari pejabat terkait, sehubungan masyarakat kita menganut kultur gemeinschap/ kebersaman/gotong royong. Edukasi ini dirasa lebih tepat guna perbaikan dalam lingkungan majemuk.

Keteladanan stakeholder merupakan bukti komitmen sportif tanggung jawab Pejabat dalam memberikan keteladanan, tetapi sejauh ini Pemda kurang peduli menyediakan transportasi umum yang memadai. (http://beritatrans.com/ 2015/11/02/2015/11/02/ kebijakan-harijumat-tanpa-kendaraan-bemotor-di-jatengtak-efektif/). Kebijakan tersebut hanya akan efektif jika transportasi publik tersedia dengan baik, layak dan jumlahnya cukup tersedia, orang akan ikhlas meninggalkan kendaraan pribadi dan beralih menggunakan angkutan umum.

Dua faktor untuk mengurangi kemacetan Lalulintas yaitu factor internal dan eksternal :

1) Faktor internal seperti : (a) penggunaan kendaraan pribadi masih mendominasi jalan raya umum, sehingga kapasitas jalan raya terkesan sempit. Pada jam-jam sibuk pada jamjam sekolah ataupun jam-jam kantor maupun jam-jam pulang kerja. Sehingga perlu dicari pemecahannya, dimungkinkan dibangun flyover karena terbukti di Jalan Jatingaleh telah teratasi; (b) belum tersedianya lahan 
parkir khusus yang dikelola secara maksimal. (c) zebra cross dan jembatan penyeberangan masih belum dimanfaatkan maksimal; (d) belum optimal dan merata sarana transportasi umum yang berdekatan dengan kantorkantor dengan tempat tinggalnya, sehingga berdampak enggan/malas. (e) belum ada peningkatkan kualitas layanan transportasi umum, bahkan sering memuat penumpang over load sehingga penumpang tidak mendapatkan kenyamanan kernet memberlakukan

tarif berlebih kepada penumpang. (f) hadirnya trasportasi online yang semakin menjamur, berdampak pada bertambahnya kemacetan transportasi.(g) Flyover Jatingaleh terbukti yang telah (difungsikan sejak tanggal 25 Agustus 2017) terbukti mengurangi kemacetan secara signifikan.

2) Faktor eksternal seperti : (a) Belum adanya kebijakan pembatasan produksi; (b) pembatasan kepemilikan kendaraan pribadi dengan syarat tertentu. Fakta menunjukkan masyarakat kota Semarang lebih dari $10 \%$ memiliki koleksi mobil mupun kendaraan roda dua yang lebih dari satu mobil, satu kendaraan roda dua. (b) belum adanya kebijakan pengenaan pajak yang lebih tinggi terhadap mereka yang telah memiliki kendaraan ganda. (c) Kebijakan pembebanan pajak Bea Masuk Kendaraan import yang cukup tinggi, agar masyarakat tidak semenamena mengimpor kendaraan.

Berbagai argumentasi yang ada, yang utama adalah perlu adanya transformasi pembentukan karakter (lebih efektif dimulai dari keluarga atau pejabat dilingkungan) untuk mencapai kesejahteraan bangsa dapat berupa keteladanan dari stakeholder maupun pejabat terkait. Proses pembentukan karakter setiap individu mengikuti mereka yang berada dalam lingkungannya, menjadi cikal bakal tidak terlupakan bahkan mendominasi keberhasilan pembentukan karakter tersebut.
Pejabat yang berhasil adalah jika pejabat teresebut mampu menciptakan karakter positif yang kuat pada anak buahnya. Edukasi publik dan Revolusi Mental dapat membantu meningkatkan pemahaman terhadap nilai-nilai luhur budaya bangsa. diharapkan dapat menjadi karakter yang menjadi landasan untuk memperkuat kebersamaan dan persatuan, toleransi, tenggang rasa, gotong royong, etos kerja dan menciptakan kehidupan kantor kyang harmonis. Pejabat memegang peran sangat penting dalam membangun perubahan mental yang dibutuhkan oleh Indonesia melalui 8 (delapan) fungsinya yang dimilikinya yaitu fungsi agama, pendidikan, cinta kasih, perlindungan, reproduksi, sosial dan budaya, ekonomi, dan lingkungan. Gerakan ini harus dilakukan secara terpadu, menyeluruh dengan memperkuat koordinasi antara pemerintah pusat dan daerah harus berkoordinasi dan bersinergi dengan pemerintah daerah dalam menangani program pembangunan mental secara operasional, utamanya memperkuat implementasi pemberdayaan delapan fungsi keluarga. Membangun jiwa yang merdeka, mengubah cara pandang, pikiran, sikap dan perilaku agar berorientasi pada kemajuan dan hal-hal yang modern, sehingga Indonesia menjadi bangsa yang besar mampu berkompetisi dengan bangsa-bangsa lain di dunia. Lawrence Friedman dalam Teori Sistem Hukum memandang hukum sebagai satu kesatuan sistem, maka diperlukan pendekatan sistem yang terdiri dari tiga komponen yakni struktur, substansi, dan kultur.( Lawrence Friedman, 1986) Komponen kultur atau budaya yang sangat dekat dengan masyarakat karena ini yang harus dilakukan masyarakat yaitu menyangkut nilai-nilai, sikap-sikap, persepsi, custom, ways of doing, ways of thingking, opinion, mempengaruhi bekerjanya hukum. Kultur ini berfungsi sebagai jembatan menghubungkan antara peraturan hukum dengan tingkah laku hukum seluruh warga masyarakat.

Ide dasar digaungkannya kembali gerakan Revolusi Mental oleh Jokowi, jiwa 
bangsa terpenting adalah jiwa merdeka, jiwa kebebasan untuk meraih kemajuan. Jiwa merdeka disebut Presiden Jokowi sebagai positivisme. Gerakan ini relevan karena Indonesia tengah menghadapi tiga problem pokok bangsa yaitu merosotnya wibawa negara, merebaknya intoleransi, melemahnya sendi-sendi perekonomian nasional. Dalam kehidupan sehari-hari, praktek Revolusi Mental adalah menjadi manusia yang berintegritas, mau bekerja keras, dan punya semangat gotong royong. Para pemimpin dan aparat negara akan menjadi pelopor untuk mnggerakkan Revolusi Mental, dimulai dari masing2 Kementrian/Lembaga(K/L). Sebagai pelopor gerakan Revolusi Mental, pemerintah lewat $\mathrm{K} / \mathrm{L}$ harus melakukan tiga hal : bersinergi, membangun manajemen isu, dan penguatan kapasitas aparatur negara.

Kebijakan Penggunaan Moda Transportasi Umum Dala Mengurangi Kemacetan Lalulintas Kota Semarang

a. Perlu sinkronisasi antar para pemangku kebijakan untuk duduk bareng membicarakan berbagai masalah terkait dengan kemacetn lalulintas yang berdampak pada kemacetan perekonomian masyarakat.

b. Melakukan pembenahan terhadap moralitas masyarakat melalui "gerakan edukasi publik" dan "Revolusi Mental" yang diawali dari pemangku kebijakan untuk mau melakukan gerakan dan gebrakan terkait dengan gerakan Jatidiri bangsa Indonesia yang bukan hanya slogan tetapi bena-benar dilakukan dengan kesadaran tinggi dan kemauan untuk mau dan mampu berbuat sesuatu demi untuk kepentingan bersama, menunjukkan bahwa bangsa Indonesia adalah bangsa yang bermatabat.

c. Langkah yang dilakukan bisa melalui gerakan untuk naik kendaraan umum, dimana hal inipun harus dan perlu untuk menambah shelter kendaraan umum, agar dapat terpenuhi prioritas ini. Jika ternyata para pemangku kebijakan tidak tertib melaksanakan, sangsi tegas atau sangsi moral harus diterapkan.

d. Dimungkinkan untuk sering diadakan lomba jalan sehat atau lomba bersepeda santai dan sebagai penyemangat diberikan hadiah bagi pemenangnya, untuk memotivasi, memacu dan mencoba untuk menyenangi bersepeda.

e. Perlu dibuat acuan atau draft setidaknya ada sedikit paksaan yang sekiranya dapat menyadarkan mereka untuk mampu berbuat sesuatu yang bermanfaat.

f. Dikembangkannya jaringan pelayanan umum;

g. Pengembangan jalur maupun jumlah alat angkutnya sekaligus schelternya ditempat-tempat yang strategis.

Mengacu pada teori kebijakan publik yang merupakan bentuk penghubung antara Pemerintah selaku penyelenggara negara kepada masyarakat selaku pelaksana kebijakan di lapangan, hasil penelitian ini dapat dipergunakan sebagai acuan guna mengambil kebijakan yang baik dan tepat. Kebijakan (policy) sebagai "the general principles by which a government is guided in its management of public affairs. (Black's Law Dictionary, Seventh Edition, Bryan A.Gamer, Editor In Chief Westgroup, ST.Paul), sebagai pedoman pemerintah dalam mengelola urusan publiknya. Dalam konten Inggris "policie" berkenaan dengan pengendalian masalah publik atau administrasi pemerintahan(William N.Dunn,2000). Harold Lasswell, tujuan utama kebijakan publik untuk menemukan (policy science) dalam merumuskan ilmuilmu kebijakan (policy sciences) harus menggunakan kajian multidisipliner dalam menentukan suatu keputusan atau kebijakan. Plester dan Stewart, pembentukan kebijakan yang baik adalah yang mengandung unsur formulated, implemented, and evaluated (James P.Lester and Joseph Stewart, 2000) artinya bahwa suatu kebijakan yang baik adalah kebijakan dapat diformulasikan, dilaksanakan, dan dievaluasi pelaksanaannya. Thomas R. Dye, 
kebijakan publik yang baik adalah kebijakan yang tidak permanen, tetapi harus selalu dapat disesuaikan dengan keadaan lingkungan. (Budi Winarno.2002). Bahkan Dye menambahkan kebijakan yang baik terdapat tiga elemen yakni terdiri atas kebijakan publik (public policy), pelaku kebijakan (policy stakeholders), dan lingkungan kebijakan (policy environment).( Budi Winarno.2002). Ketiganya saling memiliki andil dan saling mempengaruhi, lingkungan kebijakan juga mempengaruhi dan dipengaruhi oleh pembuat kebijakan dan kebijakan publik itu sendiri. Konsep-konsep di atas diimplementasikan dalam bentuk proses perumusan kebijakan yang bertujuan tercipta kesinambungan yang baik dan menghasilkan kebijakan yang prosedural tanpa menghilangkan sisi keadilan baik bagi pemerintah selaku perumus dan penyusun kegiatan maupun masyarakat selaku pelaksana kebijakan.

Kebijakan yang diambil Kota Semarang terdahulu kurang tepat, karena didasarkan pada riset yang tidak komprehensif, bersifat sepotong-sepotong. Sehingga kebijakannya kurang tepat dan tidak sinkron.(William N.Dunn,2000). Untuk kebijakan kedepan perlu dilakukan :

(1) Kehadiran BRT harus dikelola secara maksimal. Peningkatan dalam berbagai aspek, khususnya manajemen, SDM dan operasianal. Kenyamanan, efisiensi penting dalam pelayanan penumpang, karena kedua menjadi daya tawar untuk menarik simpati masyarakat agar beralih ke penggunaan transportasi umum sehingga pemakaian kendaraan pribadi berkurang.

(2) Rute BRT juga harus strategis, menjangkau masyarakat berbagai wilayah Semarang. Memfungsikan BRT secara optimal, sehingga dapat mengurangi pemakaian kendaraan pribadi.

(3) Traffic light tidak hanya di pasang di perempatan atau pertigaan jalan saja, tetapi di tempat-tempat zebra cross berada.
(4) Traffic light diberlakukan di setiap zebra cross, dikontrol sendiri oleh penyeberang jalan karena di tiap tiang traffic light diberi tombol ketika di pencet dalam 10 detik traffic light akan menyala merah, sehingga penyeberang jalan dapat menyeberang dengan aman tanpa menunggu lama hingga kendaraan habis.

(5) Membudayakan jalan kaki di area pusat kota seperti simpang lima, bisa menjadi solusi alternatif untuk mengurangi pemakaian kendaraan pribadi. Di sepanjang trotoar bisa dibuat agar para pejalan kaki merasa nyaman dengan ditanami pepohonan di setiap sisisisinya, sehingga dapat menciptakan kerindangan.

(6) Meningkatkan perbaikan di area "city walk" khususnya di sepanjang jalan Pandanaran, kawasan Simpang Lima, Johar serta tempat-tampat tertentu yang strategis, diharapkan menjadi kota yang nyaman dan tertib.

(7) Kerja sama pemerintah, masyarakat, aparat secara komprehensif, akomodatif berwawasan kedepan, menanamkan kepedulian, memberikan keteladanan sosial yang dimulai dari aparat/pejabat terkait secara rutin, sehingga masyarakat bawah setidaknya dalam jajarannya pasti meneladan rela/ikhlas.

(8) Penertiban Pedagang kaki lima yang menempati trotoar dipindah yang lebih sesuai demi ketertiban dan keindahan kota.

\section{Simpulan dan Saran}

1. Kebijakan Transportasi sampai kini belum berhasil optimal, tetapi mengalami kemajuan:
a. Menyikapi Surat Keputusan
Gubernur Jawa Tengah Nomor 550/54 Tahun 2015 dan Surat
Edaran Sekretaris Daerah Provinsi Jawa Tengah Nomor 550/016847 tentang Penerapan Hari Bebas Kendaraan Bermotor Bagi Instansi Pemerintah Provinsi Jawa Tengah 
Tahun 2015 sampai tahun 2020, sebagian besar Karyawan mematuhi,tetapi sebagian masih menggunakan kendaraan pribadi/Dinas tetapi diparkir ditempat lain.

b. Kebijakan penanggulangan "rob" ada kemajuan setidaknya $15 \%$ arah jalan Kaligawe sampai arah pasar Genuk, sekitar Pasar Johar, Jalan Kakap telah berkurang, Perumahan Hasanudin, Kokrosono karena dilengkapi pompa sedot air otomatis.

2. Kebijakan Transportasi Umum Kota Semarang sampai kini masih belum berhasil tuntas terkurangi kemacetan Lalulintas karena faktor internal dan faktor eksternal.

1) Faktor internal : (a) pengguna pribadi masih belum beralih ke kendaraan umum; (b) belum tersedia lahan parkir secara khusus.(c) zebra cross dan jembatan penyeberangan belum dimanfaatkan optimal, (d) belum ada penambahan shelter dekat kantor guna meningkatkan kualitas layanan transportasi umum. (e) Flyover agar dilengkapi rambu lalu lintas dan penertiban transportasi online .

2) Faktor eksternal seperti : a) Belum ada Pembatasan produksi pada produsen; b) Pembebanan pajak lebih tinggi bagi pemilik kendaraan ganda; c) pembatasan pemilik kendaraan untuk masyarakat.

3. Kebijakan Penggunaan Moda Transportasi Umum Dalam Rangka Mengurangi Kemacetan Lalulintas Kota Semarang, nelalui kebijakan : a) pengembamgan kebijakan sarana prasarana cenderung berdampak negative, b) dekonstruksi Melalui pengkajian, mengontrol, mengevaluasi kebijakan, dialog pejabat dan masyarakat, memberi contoh memanfaatkan transportasi umum, d)Peraturan tegas disinkronkan kebijakan yang telah ada, bebas polusi, kerja bakti mempercantik lapangan umum, optimalisasi kawasan "city walk”,trotoar khusus pejalan kaki, Rute transportasi umum strategis, e) efektifkan Zebra cross, Traffic light otomatis, dikontrol dan setiap tiang diberi tombol penyala otomatis.

\section{DAFTAR PUSTAKA}

C.Bryan A.Gamer, Black's Law Dictionary, Seventh Edition, Editor In Chief Westgroup, ST.Paul, Minn.

Kamus Besar Bahasa Indonesia Pusat Bahas, Edisi IV, (Jakarta: Gramedia Pustaka Utama, 2012).

Lester, James P. \& Joseph Stewart. 2000. Public Policy : An Evolutionary Approach. California: University of California Wasworth Thomson Learning

Parikesit, D. 2007. Menggagas Tatanan Baru Transportasi Bagi Indonesia Yang Maju dan Sejahtera. Pidato Pengukuhan Jabatan Guru Besar, Fakultas Teknik, Universitas Gadjah Mada. Yogyakarta.

Satria Hibatal Azizy, 2015, Mendudukkan Kembali Makna Kesejahteraan Dalam Islam, Ponorogo Jatim: Kampus Baru UNIDA.

Warrasih, Esmi. 2011. Pranata Hukum Sebuah Telaah Sosiologis. Semarang : Badan Penerbit Universitas Diponegoro

\section{Jurnal/Artikel}

Journal Systems, Vol 8, No 16 (2010) > Majalah Ilmiah Universitas Pandanaran, Jurnal Manajemen Tansportasi \& Logistik (ONLINE eISSN 2442-3149 | PRINT pISSN 2355-472X) > Iwan Prayoga, Desain Berkelanjutan (Sustainable Design).

"The Human Development Index:Yet Another Redundant Composite Development" Indicator dalam World Government, Vol. 19 No.10.(Great Britain: Pergamon Press, 1991) > Mark Mc Gillivray.

Jurnal Media Center Kominfo Jawa Tengah Jurnal Transportasi Vol. 9 No. 1 Juni 2009: 
36-47 > Lyon, et al. 2001. Transport Visions, Transportation Requirements (The Second of eight reports from the Transport Vision Network). Transportation Research Group, University of Southampton Landor Publishing Ltd Quadrant House 250 Kennington Lane. London.

Riptek Vol.10. No. 1, Tahun 2016 Semarang Butuh Pembenahan Transportasi, Kompas.com- 16 /03/2009 diakses tgl 19 Oktober 2018

Malkhamah,S, 2007, Keuntungan Penyediaan dan Penggunaan Angkutan Umum untuk Masyarakat Perkotaan. Pidato Penggukuhan Jabatan Guru Besar, Fakultas Teknik, Universsitas Gajah Mada, Yogyakarta

\section{Internet :}

http://beritatrans.com/2015/11/02/kebijakanhari-jum'at-tanpa-kendaraan-bermotordi-jateng-takefektif/\#sthash.vezm3jVm.dpuf http://iinsetya14.blogspot. co.id/2015/12/bab-i-pendahuluani.html December 20, 2015, Hukum Pengangkutan, Pengangkutan Darat > diakses tg 22/1/2018 jam 7.30

http://repository.umy.ac.id/handle/1234567

89/8909 tentang diakses tgl 5 Agustus 2018 jam 21.37 > Dampak Kemacetan Kota Yogyakarta Terhadap Kepuasan Wisatawan Kota Yogyakata Tahun 2016

http://repository.umy.ac.id/handle/12345678 9/8909 diakses tgl 5 Agustus 2018 jam 21.37

http://www.prosperity.com/ > Prosperity Index disebut juga dengan Legatum Prosperity Index, merupakan salah satu indikator kesejahteraan yang dikembangkan oleh Legatum Institute London Inggris. Index ini meliputi bidang ekonomi, kewirausahaan dan kesempatan kerja, kinerja pmrintah, pendidikan, kesehatan, keamanan, kebebasan individu dan modal sosial. http://www.prosperity.com/

http://www.numbeo.com/quality-of;ife/rankings_by_country.jsp

http://datakesra.menkokesra.go.id/datakesra/ kemiskinan_pemberdayaan/data-indekskesejahteraan-rakyat-ikrar 